\title{
SIMULATION OF MICROBIOLOGICAL DESTRUCTION PROCESS OF OIL POLLUTION IN SHALLOW WATER*
}

\author{
A.A. Filina ${ }^{1}$, V.V. Sidoryakina ${ }^{2}$, A.E. Chistyakov ${ }^{3}$, A.V. Nikitina ${ }^{3,4}$ \\ ${ }^{1}$ Supercomputers and Neurocomputers Research Center, Taganrog, Russia \\ ${ }^{2}$ Taganrog Institute after A.P. Chekhov (branch) of RSUE, Taganrog, Russia \\ ${ }^{3}$ Don State Technical University, Rostov-on-Don, Russia \\ ${ }^{4}$ Southern Federal University, Rostov-on-Don, Russia
}

$\square$ j.a.s.s.y@mail.ru,cvv9@mail.ru, cheese_05@mail.ru, nikitina.vm@gmail.com

The paper covers the research of microbiological destruction processes of petroleum origin pollutants in a shallow water taking into account a number of determining factors that affect the distribution of pollution in the researched water area: the oil fractional composition, the processes of evaporation, dissolution, biological oxidation of petrohydrocarbons by microorganisms, as well as hydrodynamic and chemical-biological features of the water. A complex of interrelated spatially inhomogeneous mathematical models was proposed that allow researching the dynamics of microbiological destruction processes of petroleum hydrocarbons in shallow water. Schemes with weight taking into account the partial filling of computational cells of the simulated domain were developed at model discretization that made it possible to significantly increase the accuracy of calculations and reduce the calculation time. Based on a multiprocessor computer system, experimental software has been developed for predictive modeling of the ecological situation of shallow water in the event of accidental pollution by oil and other harmful substances during natural and technogenic challenges.

Keywords: microbiological destruction, oil, shallow water, parallel algorithm, software, computer system.

Introduction. The problem of oil pollution at the end of the XX century has acquired global proportions. Oil has become one of the energy sources. However, the imperfection of extraction, transportation, processing and storage technologies leads to significant losses, to pollution of the atmosphere, soils, waters, as well as negative effects on humans, flora and fauna. Oil enters the water as a result of its natural exits to the surface in the areas of occurrence, as well as oil production, oil refining, transportation and use as industrial raw materials and fuel. To maintain the sustainable development of aquatic ecosystems, it is necessary to develop a set of methodological tools that allow assessing and developing recommendations and rules for the sustainable development of shallow waters, maintaining the biocenoses of aquatic ecosystems, especially in case of catastrophic situations [1]. Currently, water pollution monitoring systems are being actively created. It based on a number of problems aimed at researching the current state of the selected aquatic ecosystem, including monitoring the level of water pollution and bottom sediments of rivers, lakes, reservoirs and seas by physical, chemical and hydrobiological indicators in order to study the of pollutant distribution in time and space; assessment and forecast of water environment situation.

\footnotetext{
* The reported study was funded by RFBR according to the research project № 19-01-00701.
} 
It is known that oil and its refined products are one of the most toxic and harmful pollutants included in the list of mandatory indicators controlled at monitoring the water ecosystem pollution. Oil is a complex mixture of hydrocarbons, naphthenic acids, asphaltenes, resins and other components. When oil enters a reservoir, it undergoes various destructive processes: evaporation, microbiological oxidation, dissolution, precipitation, etc., which depend on the type and fractional composition of oil, volume, its initial physical and chemical properties of oil, as well as natural and climatic conditions during the entire period of the substance's stay in the water. According to the available data, the losses of crude oil are up to $60 \%$ during evaporation of the light fraction, up to $30 \%$ - during biodegradation by bacteria, up to $15 \%$ - during precipitation, up to $15 \%$ - during the formation of the «oil in water» and «water in oil» emulsion, up to $10 \%$ - during dissolution and up to $5 \%$ - during photo-oxidation [2].

Oil spill response plans are developed in accordance with various regulatory and legal documentation, the requirements of the Decree of the Government of the Russian Federation No. 613 of August 21, 2000 "On urgent measures for the prevention and Elimination of Emergency Spills of oil and Petroleum products" (as amended and supplemented on April 15, 2002), and Order of the Ministry of Emergency Situations of Russia No. 621 of December 28, 2004 "On Approval of the Rules for the Development and Coordination of Plans for the prevention and Elimination of oil and Petroleum Products Spills on the Territory of the Russian Federation". The International Association of Representatives of the Oil Industry for Environmental Protection (IPIECA) has issued a Guide for planning actions in emergency situations in case of oil spills, which also reflects the issues of developing an oil spill response plan. The action plan in the event of an emergency related to oil spills should include three main tasks:

- development of strategies that should describe the plan, its geographical scope, perceived risks and the roles/responsibilities of those entrusted with the task of implementing the plan and strategy of proposed spill response measures;

- preparation of an action plan and work indicating the implementation of emergency procedures for the possibility of rapid assessment of the spill and the mobilization of appropriate resources for its elimination;

- creation of information data resources, which should include all necessary maps, lists of resources and data tables for ensuring the measures to eliminate the oil spill and conduct the liquidation itself in accordance with the agreed strategy.

The behavior and distribution of oil in a watercourse is determined by the sum of the following processes: evaporation, emulsification, dissolution, oxidation, formation of oil aggregates, sedimentation, and biodegradation [3]. Fig. 1. shows the general scheme of these processes.

The causes and consequences of the explosion of the BP Deepwater Horizon oil platform in the Gulf of Mexico on April 20, 2010 are still the subjects of debate among economists and politicians, as well as scientists. Less than a week has passed since the publication of the work on the detection of an oil plume at a depth of about a kilometer in the waters of the Mexico Gulf, as a new article on this topic appeared in the Science journal.

Oil pollution disrupts many natural processes and relationships, significantly changes the living conditions of all types of living organisms and accumulates in the biomass. The negative impact of oil pollution on aquatic ecosystems is associated both with a violation of the interaction processes 
of water with the atmosphere, and with the accumulation of secondary pollutants in them. The oil that gets into the body can cause gastrointestinal bleeding, kidney failure, liver intoxication, blood pressure disorders. Fumes from oil vapors lead to respiratory problems in mammals that are near or in close proximity to large oil spills. Fish are exposed to oil spills in the water at eating contaminated food and water, as well as when they encounter oil during the movement of eggs. The death of fish, excluding juveniles, usually occurs in serious oil spills. However, crude oil and petroleum products differ in a variety of toxic effects on different types of fish. The oil concentration of 0.5 millionth of a fraction or less in the water can lead to the death of trout. Oil has an almost lethal effect on the heart, changes breathing, increases the liver, slows down growth, destroys fins, leads to various biological and cellular changes, and affects behavior. Larvae and juveniles of fish are most sensitive to the effects of oil, spills of which can destroy fish eggs and larvae located on the surface of the water, and juveniles - in shallow waters. The impact of oil spills on invertebrates can last from a week to 10 years. It depends on the type of oil, the circumstances under which the spill occurred and its impact on organisms. Invertebrates most often die in the coastal zone, in sediments or in the water column. Invertebrate colonies (zooplankton) in large water volumes return to their previous state (before the spill) faster than those that are in small water volumes. Water plants completely die if the concentration of polyaromatic hydrocarbons (formed during the combustion of petroleum products) reaches $1 \%$.

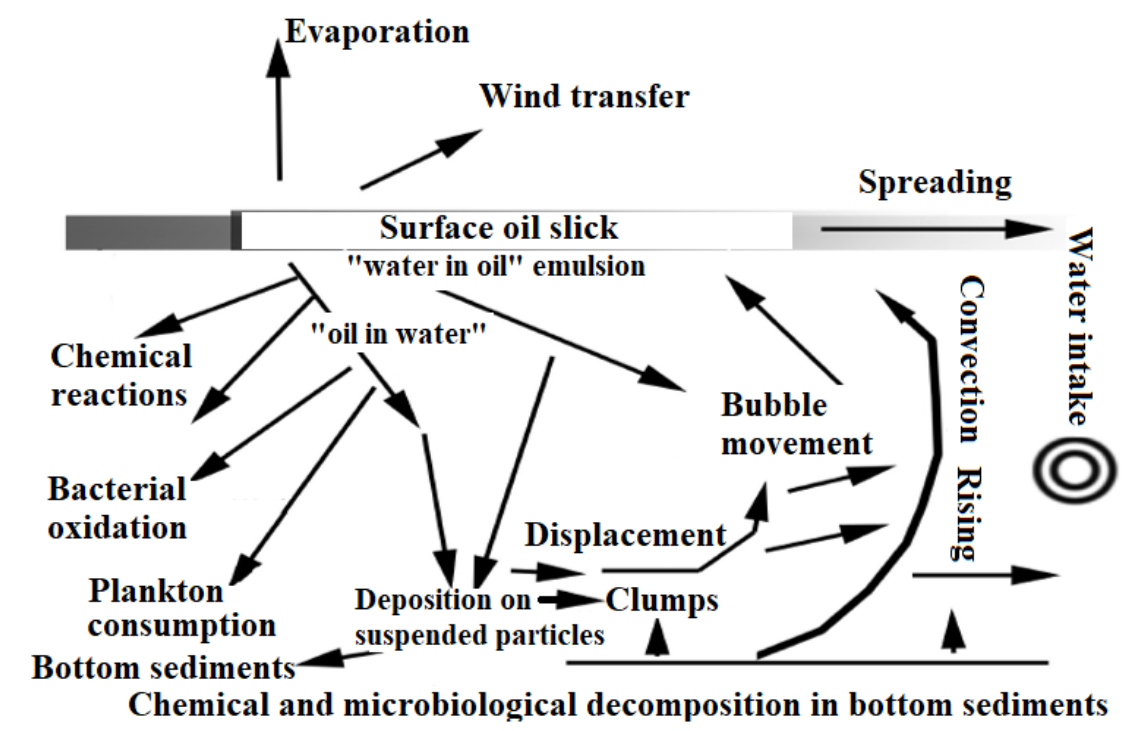

Fig. 1. Cycles of oil transformation in water

Most researchers recognize the leading role in the destruction of oil pollution of the processes of dissolution and oxidation of oil, consider them as a redistribution of components already present in oil between the gas phase, an aqueous solution, and, in fact, oil [4]. This approach cannot be considered comprehensive because it involves only the transfer of pollutants from one migration form to another, without affecting the formation of new previously non-existent components or the complete destruction of existing forms.

Immediately after the spill, the oil begins to spread over the water surface. The propagation velocity largely depends on the viscosity and volume of spilled oil. Liquid petroleum products 
initially spread as a cohesive spot that quickly fragments. Oil takes the form of narrow strips or ribbons parallel to the wind direction in an open water, under the influence of wind circulation. The following processes also have a significant impact on the rate of propagation and fragmentation of an oil slick: evaporation; dispersion; dissolution; microbiological destruction; photo-oxidation; settling of heavy fractions of petro-hydrocarbons; wave action; turbulence; tidal currents, etc.

These processes are especially intense in the period up to one day from the moment of the oil spill. Only mixing of heavy fractions with suspended matter in water and individual components of the bottom (silt, sand, bottom sediments) occurs within a few days to a month or more. Therefore, it is necessary to make a qualitative and accurate prediction of the behavior of oil spills in the water area of coastal systems to avoid the negative consequences of accidental oil spills and its refined products that affect natural ecosystems and human life in general.

Mathematical model of the petroleum products transport. To research the dynamics of of oil pollution behavior in the shallow water area, a mathematical model of the petroleum products transport subject to evaporation of light, neutral and non-evaporating pseudo-fractions of oil slick, dissolution of oil slick and biodegradation was developed, which has the form $[5,6]$ :

$$
\begin{gathered}
\left(c_{i}\right)_{t}^{\prime}+u\left(c_{i}\right)_{x}^{\prime}+v\left(c_{i}\right)_{y}^{\prime}=\left(\mu *\left(c_{i}\right)_{x}^{\prime}\right)_{x}^{\prime}+\left(\mu *\left(c_{i}\right)_{y}^{\prime}\right)_{y}^{\prime}-\alpha_{i}(T)-\beta_{i}\left(c_{i}\right) M,\left.\quad\left(c_{i}\right)_{n}\right|_{(x, y) \in \gamma}=0, \\
M_{t}^{\prime}+\left(u+u_{M}\right) M_{x}^{\prime}+\left(v+v_{M}\right) M_{y}^{\prime}=\left(\mu M_{x}^{\prime}\right)_{x}^{\prime}+\left(\mu M_{y}^{\prime}\right)_{y}^{\prime}+\gamma_{M}\left(c_{i}\right) M-\lambda M,\left.M_{n}^{\prime}\right|_{(x, y) \in \gamma}=0, \\
\left(\varphi_{i}\right)_{t}^{\prime}+u\left(\varphi_{i}\right)_{x}^{\prime}+v\left(\varphi_{i}\right)_{y}^{\prime}+w\left(\varphi_{i}\right)_{z}^{\prime}=\left(\mu\left(\varphi_{i}\right)_{x}^{\prime}\right)_{x}^{\prime}+\left(\mu\left(\varphi_{i}\right)_{y}^{\prime}\right)_{y}^{\prime}+\left(\mu\left(\varphi_{i}\right)_{z}^{\prime}\right)_{z}^{\prime}, \\
\left.\left(\varphi_{i}\right)_{n}^{\prime}\right|_{(x, y, z) \in \Gamma(z=0)}=0,\left.\quad\left(\varphi_{i}\right)_{z}^{\prime}\right|_{z=0}=\varphi_{i 0},
\end{gathered}
$$

where $c_{i}$ is the concentration of $i$-th oil fraction; $\rho_{\omega}, \rho$ are the water and oil densities, respectively; $\mu^{*}=\mu+\left(\rho-\rho_{\omega}\right) g h^{3} / \mu$ is a function describing the decomposition process of a contaminant; $\mu$ is the diffusion coefficient; $g$ is the gravitational acceleration; $h=\sum_{1}^{l} c_{i}$ is the slick thickness, $i=\overline{1, k}$ $; \alpha_{i}, \beta_{i}$ are coefficients that take into account the decrease in the concentration of the oil light fraction as a result of evaporation, dissolution and bacterial decomposition; $M$ is the concentration of microorganisms; $\mathbf{u}_{M}=\left(u_{M}, v_{M}\right), u_{M}, v_{M}$ are velocity components of microorganisms movement relative to the water; $\gamma_{M}=\gamma_{M}\left(c_{i}, T\right)$ is the growth rate of microorganisms; $\lambda$ is the rate of cell death; $q$ is a proportionality coefficient between the number of bacteria and the absorbed substrate; $\varphi_{i}$ is the concentration of $i$-th oil fraction in the dissolved state, $i=\overline{k+1, l}$.

To solve the above system of equations, the initial conditions were determined in the case of a single-stage oil release:

$$
\left.c_{i}\right|_{t=0,(x, y) \in S_{0}}=c_{i 0},\left.c_{i}\right|_{t=0,(x, y) \notin S_{0}}=0,
$$

where $S_{0}$ is a domain, covered by an oil slick; $c_{i 0}$ is an oil concentration in the considered domain. 
For complex climatic and hydrodynamic conditions of the Azov-Black Sea basin, the coefficient of horizontal turbulent diffusion, which is neglected in the currently known models of oil products transport, obeys Richardson's "four-thirds" law and is determined as follows [7]:

$$
\mu \approx \varepsilon^{1 / 3} L^{4 / 3}
$$

where $L$ is the characteristic size of the pollutant slick; $\varepsilon$ is the value of the turbulent energy dissipation rate (at the surface is about $10^{-1}-1 \mathrm{~cm}^{2} / \mathrm{s}^{3}$ and on average decreases to values of $10^{-4}-10^{-3}$ $\mathrm{cm}^{2} / \mathrm{s}^{3}$ with the increasing of depth).

Functional dependencies (observation models) are introduced in the system (1), (2) to research the microbiological destruction processes of oil pollution, including the processes of evaporation, dissolution, and biological oxidation by microorganisms (Table 1).

The change in the initial solubility of oil is described by the following equation:

$$
S=S_{0} e^{-0,1 t}
$$

here $S_{0}$ is the initial oil solubility; $t$ is the time.

Table 1. Functional dependences of microorganisms' growth rate

\begin{tabular}{|c|l|}
\hline \multicolumn{1}{|c|}{ Functional dependences } & \multicolumn{1}{c|}{ Designations } \\
\hline$\gamma_{M}\left(c_{i}\right)=\mu_{m} c_{i} /\left(c_{i}+K_{i}\right)$ & $\begin{array}{l}\mu_{m}(T, C, I) \text { is the maximum growth rate of } \\
\text { microorganisms; } M \text { are bacteria; } T \text { is the ambient } \\
\text { temperature above the slick surface; } C \text { is the salinity; } \\
I \text { is the illumination; } K_{i} \text { is the saturation coefficient }\end{array}$ \\
\hline$\alpha_{i}(T)=\left(K_{E} P_{i} /(R T)+K_{D} S_{i}\right) A X_{i} M_{i}^{m}$ & $\begin{array}{l}K_{E}=2,5 \cdot 10^{-3} U^{0,78} \text { is the mass transfer coefficient } \\
\text { for carbon, }[\mathrm{m} / \mathrm{s}] ; U \text { is the wind velocity relative to } \\
\text { the water, [m/s]; } X_{i} \text { is the molar fraction of } i \text {-th oil } \\
\text { fraction, equaled to the } v_{i} / \sum v_{i} ; v_{i} \text { is the amount of } \\
\text { substance of } i \text {-the oil fraction, [mol]; } P_{i} \text { is the vapor } \\
\text { pressure of } i \text {-th component [Pa]; } R \text { is the universal gas } \\
\left.\text { constant, } R=8,314 \mathrm{~J} / \mathrm{mol} ; A \text { is an oil spill area, [m }{ }^{2}\right] ; \\
M_{i}^{m} \text { is the value of the molar mass of } i \text {-th fraction } \\
{[\mathrm{kg} / \mathrm{mol}] ; \quad K_{D}=k K_{D 0} \text { is the mass transfer }} \\
\text { coefficient of dissolution; } K_{D 0} \text { is the initial value of } \\
\text { the mass transfer coefficient of dissolution; } k \text { is a } \\
\text { coefficient depending on the wave of the researched } \\
\text { water system; } S_{i} \text { is the solubility of } i \text {-th component in } \\
\left.\text { the water, [kg/m }{ }^{3}\right]\end{array}$ \\
\hline
\end{tabular}

Taking into account the food tax (the microorganisms movement in the direction of increasing the concentration of food-oil fractions), it was assumed that the number of microorganisms increases as much as possible at moving along the gradient $c_{i}$ [8].

Simulation of the microbiological destruction processes of oil pollution taking into account the variety of bacteria. Bacterial exposure is characterized by high selectivity, and the complete decomposition of all oil components requires exposure to bacterioplankton of various 
species. In this case, a number of intermediate products are formed, which can both be sedimented into the soil and decompose further. It has been experimentally established that the destruction proceeds in time according to a ratio close to the laws of the monomolecular reaction, but the rate constants vary within very wide limits and depend on the temperature, the concentration of oxygen dissolved in water, the number of bacterioplankton, its composition, the type of bottom sediments, etc. Part of the decomposition products of oil in the form of poorly soluble compounds, as well as in the sorbed or self-deposited state with suspended substances, settles to the bottom, forming bottom sediments [9].

The water column contains a number of microorganisms that can metabolize oil-containing compounds. These include bacteria, various types of mold, yeast substances, fungi, single-celled algae and protozoa that use oil as a source of carbon and energy. The main factors affecting the rate and degree of biodegradation are the characteristics of oil, its fractional composition, the presence of oxygen in the reservoir and biogenic substances (mainly nitrogen-containing and phosphoruscontaining compounds), as well as the temperature level. During the hydrocarbons decomposition, a number of intermediate compounds are formed; the final biodegradation products are carbon dioxide and water. Each of the microorganisms types involved in this process causes the decomposition of a certain group of petro-hydrocarbons. Simultaneous or sequential exposure to a wide range of microorganisms is necessary to continue the biodegradation process. A complex community of microorganisms develops in the decomposition process. There are a small number of them at a distance from the shore, but they multiply quickly in the presence of oil until the process is limited by a lack of nutrients or oxygen.

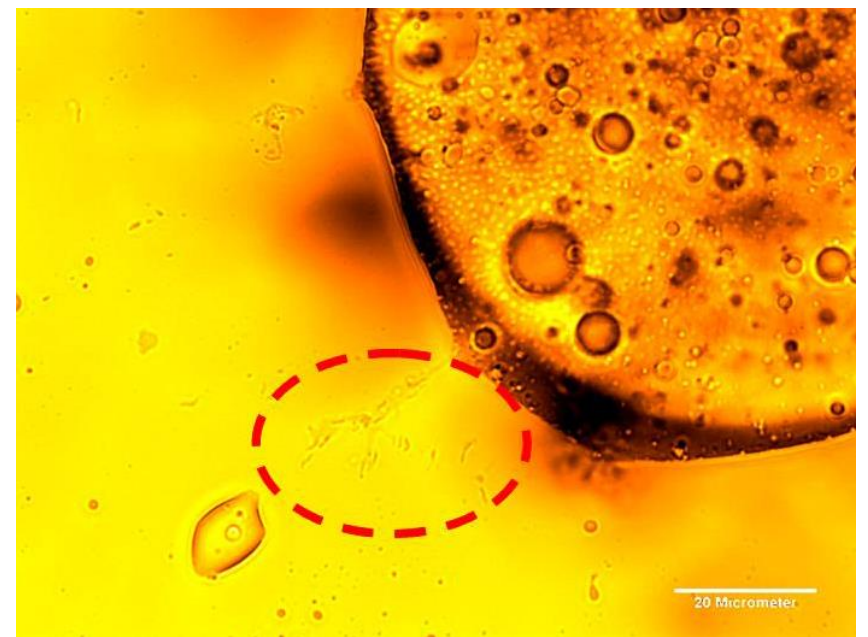

Fig. 2. Bacterial decomposition of oil droplets spilled in the Mexico Gulf

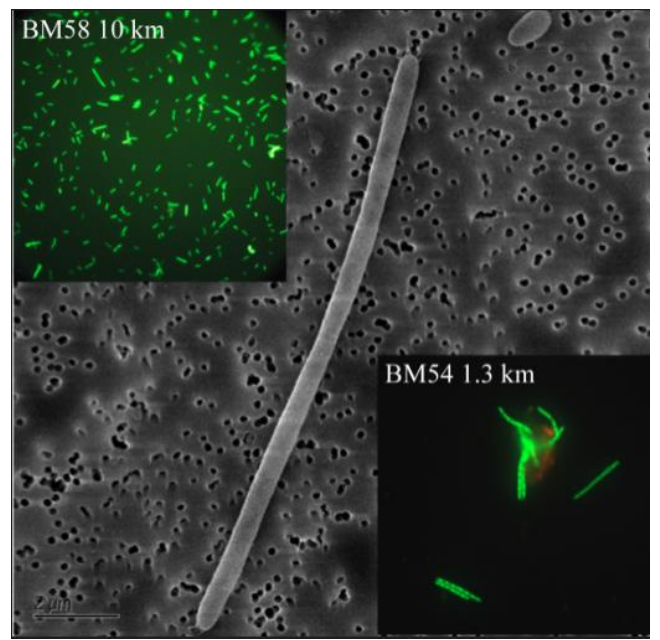

Fig. 3. Bacteria that dominate in the oil decomposition process

Specialists of the National Laboratory named after Lawrence at Berkeley, part of the University of California, drew attention not only to the research of the size and properties of the oil plume formed about $16 \mathrm{~km}$ from the source of hydrocarbons, but also to its microbiological world (Fig. 2). They found that the activity of microbes (including several unknown species) in the plume is very high, which allows the oil to decompose at a record pace (Fig. 3). In addition, they found that in this case, the oil degradation occurs without the usual noticeable decrease in the level of oxygen in 
the water, and, therefore, standard methods for assessing the activity of bacteria (taking into account just the intensity of their respiration) are not suitable for obtained data processing.

Biotic processes of oil and petroleum products transformation are more active [10]. When oil and petroleum products are decomposed by microorganisms, there are two types of hydrocarbon transformation processes. The first type is characterized by the following processes: hydrocarbons decompose to low-molecular organic acids, which can participate in natural carbon cycles. At the same time, the following transformations occur: bioconcentration is the assimilation of carboncontaining substances directly from the environment, without taking into account the intake with nutrition; bio-multiplication is the assimilation of these substances during nutrition; bioaccumulation - assimilation according to the first and second types; ecological enrichment is the increasing of substance concentration in the ecosystem during the transition from its lower level to a higher one. The second mechanism is cometabolism. As a result of the processes of oxidation, reduction, and hydrolysis, xenobiotics are embedded in the macromolecules of organic substances. It is assumed that it is possible to embed the products of the destruction of petroleum hydrocarbons into the humus structure and fix them. The transformation processes depend on the hydrocarbons composition and the structure of the molecules of organic substances. The self-purification processes of the biosphere from oil and petroleum products are of ecosystem importance. These processes depend on the properties of the oil itself, as well as on external conditions, especially climatic ones.

To eliminate oil pollution, various biological products containing viable cells as separate strains of hydrocarbon-oxidizing microorganisms (for example, «Putidoil», «Olevorin»), as well as bacterial consortia («Devoroil») are used [11]. It is known that to increase the efficiency of oil biodegradation, mixed cultures are often used, including two or more types of microorganisms. Biosorbents are used to clean the surface of natural and artificial waters, wastewater and liquid industrial waste from oil and petroleum products contamination with simultaneous disposal of contamination by microorganisms, using which there is an increase in the speed and completeness of biodegradation of oil and toxic petroleum products. The biosorbent, widely used for cleaning reservoirs from oil and petroleum products, includes as a carrier a hydrophobic petroleum sorbent based on peat and oil-oxidizing microorganisms immobilized on the carrier in an effective amount. The microorganisms immobilized on the carrier are performed by an adsorption method to obtain individual sorbents: bacterial with Rhodococcus eqvi P-72-00 culture, yeast with Rhodotorula glutinis 2-4 $\mathrm{M}$ culture and mushroom with Trichoderma lignorum F-98 mycelial fungus. At the same time, the complex biosorbent for purification contains a composition of individual sorbents, with the following ratio of components, wt.\%: bacterial with Rhodococcus eqvi P-72-00 45-55 culture; yeast Rhodotorula glutinis 2-4 M 45-55 culture, or bacterial with Rhodococcus eqvi P-72-00 45-55 culture; mushroom with Trichoderma lignorum F-98 45-55 mycelial fungus, or bacterial with Rhodococcus eqvi P-72-00 40-50 culture; yeast with Rhodotorula glutinis 2-4 M 20-35 culture; mushroom with Trichoderma lignorum F-98 25-35 mycelial fungus. However, the means designed to increase the rate of oil biodegradation are not effective enough due to the lack of nutrients, especially in coastal waters, and the low possibility of increasing the oxygen level or water temperature. Microorganisms live in water, from which they get oxygen and the necessary nutrients. Therefore, the microbiological destruction process occurs only in the water column. The formation of oil droplets in water increases the surface area where biological activity is possible, and thus the biodegradation is enhanced. Oil 
has a limited surface area in thick layers on coastlines or above the full water mark and limited contact with water. Here, the process of biodegradation is extremely slow, as a result of which the oil is not eliminated, it remains for many years. At the same time, oil-soluble dispersants are poorly soluble in water, and there is a problem of their use in the form of dilute solutions. The use of a concentrated reagent in undiluted form leads to high consumption of it when used on large areas. In addition, the use of a concentrated reagent without preliminary dilution can lead to its local overdoses with intensive formation of a stable direct microemulsion of oil in water. At the same time, the maximum permissible concentration of oil and the dispersant in the area of its application may be significantly exceeded. Therefore, the biological oil destruction process is particular interest at researching the dynamics of oil pollution as the main long-term mechanism of natural elimination from coastal territories and shallow-water ecosystems. Technological equipment for processing film oil with chemical reagents should ensure a uniform distribution of the dispersant solution over the width of the capture with the necessary level of mechanical impact on the oil film. A flat jet performs processing of the oil slick with a dispersant.

The tendency of spilled oil to rapidly spread and fragment, especially in storm conditions, limits the effectiveness of accident response methods. The movement of oil slicks and the changing nature of oil as a result of weathering indicate the need for measures in addition to monitoring the dispersion of pollution. Depending on the physical and chemical properties of the spilled oil, many widely used dispersants become significantly less effective due to changes in the viscosity of the oil. With an increase in the viscosity of oil more than $10,000 \mathrm{cSt}$, most dispersants completely cease to act. The oil viscosity can increase very quickly, and therefore the acceptable period of biosorbents' use is very short. Therefore, the use of dispersants should be regularly monitored, and spraying operations should be discontinued in case of loss of their effectiveness.

The dependencies were used to describe the dynamics of the oil-oxidizing microorganisms' population, taking into account their death [12]. The growth of microbial populations per unit of time is proportional to the value of the oil slick concentration and depends on the amount of limiting substrate, the decrease in the values of the number of populations occurs due to the natural mortality of microorganisms: $\partial M_{j} / \partial t=F\left(c_{i}\right) M_{j}$, where $M_{j}$ is the the number of bacterial population of $j$-th type; $\mathrm{t}$ is the time; $F$ is a function of both the number itself and the time and depends on various external and internal factors.

The dependence of the growth rate $F$ on the amount of substrate (petro-hydrocarbons) is described by the Mono equation as follows: $F\left(c_{i}\right)=\frac{\mu_{m}(T(t)) c_{i}}{c_{i}+K_{i}(T(t))}$, where $\mu_{m}$ is the maximum possible rate of bacterial growth with an excess of substrate; $M$ is the substrate concentration; $K_{c}$ is the saturation coefficient with a dimension similar to the dimension of the substrate; $T(t)$ the temperature at which the population of oil-oxidizing microorganisms changes in a unit of time.

Taking into account the above provisions, as well as the fact that all the hydrocarbons that make up the oil remaining after the evaporation of its volatile components are attacked by various types of marine bacteria, the system of equations that describes the dynamics of changes in the number of microorganisms populations that subject oil pollution to oxidation, taking into account the 
limited substrate, convective-diffusion transfer of oil slick with the varying pseudofractions' concentration during the microbiological destruction by bacteria of several species has the form [13]:

$$
\begin{gathered}
\left(M_{j}\right)_{t}^{\prime}+u\left(M_{j}\right)_{x}^{\prime}+v\left(M_{j}\right)_{y}^{\prime}=\left(\mu\left(M_{j}\right)_{x}^{\prime}\right)_{x}^{\prime}+\left(\mu\left(M_{j}\right)_{y}^{\prime}\right)_{y}^{\prime}+\frac{M_{j}}{q} \sum_{i=1}^{n} \frac{\mu_{i j} c_{i}}{c_{i}+K_{i}}-\sum_{j=1}^{m} \lambda_{j} M_{j}, \\
\left.M_{j}\right|_{t=0}=M_{j 0},\left.\left(M_{j}\right)_{n}^{\prime}\right|_{(x, y) \in \gamma}=0
\end{gathered}
$$

where $c_{i}$ is the concentration of $i$-th oil pseudofraction; $M_{j}$ is the number of $j$-th bacterial species; $M_{j 0}$ is the initial concentration of $j$-th bacterial species; $\lambda_{j}$ is the death rate of $j$-th type of bacteria; $\mu_{i j}$ is the value of the maximum growth rate of $j$-th type of bacteria at eating of $i$-th oil pseudofraction; $q$ is the value of the proportionality coefficient between the number of bacteria and the absorbed substrate; $K_{i}$ is the saturation coefficient with a dimension similar to the dimension of the substrate. The second equation of the system (1) was substituted by equation (1').

At modeling the biodegradation processes of oil pollution in a shallow reservoir, it was taken into account that the chemical processes of transformation of oil and petroleum products include: oxidation with molecular, atomic oxygen, ozone, hydrogen peroxide; photochemical decomposition under the influence of ultraviolet radiation, when under the influence of sunlight there is a complete decomposition of hydrocarbon molecules to simple substances, for example, $\mathrm{CO}_{2}, \mathrm{CO}, \mathrm{H}_{2} \mathrm{O}$.

Problem discretization. The computational domain $\bar{G}$ has a complex, dynamically changing shape, which is inscribed in a rectangle. To construct a difference scheme, we introduce a uniform computational grid:

$$
w_{h}=\left\{t^{n}=n \tau, x_{i}=i h_{x}, y_{j}=j h_{y} ; n=\overline{0, N_{t}}, i=\overline{0, N_{x}}, j=\overline{0, N_{y}} ; N_{t} \tau=T, N_{x} h_{x}=l_{x}, N_{y} h_{y}=l_{y}\right\},
$$

where $h_{x}, h_{y}$ are steps on spatial variables; $N_{x}, N_{y}$ are boundaries by spatial variables; $\tau$ is the time step; $N_{t}$ is the upper time boundary; $l_{x}, l_{y}$ are domain dimensions.

The scheme with weights was used to approximate the problem (1) - (3) by the time coordinate [14]:

$$
\frac{\hat{c}-c}{h_{t}}+u \overline{c_{x}^{\prime}}+\mathrm{v} \overline{c_{y}^{\prime}}=\left(\mu \overline{c_{x}^{\prime}}\right)_{x}+\left(\mu \overline{c_{y}^{\prime}}\right)_{y}^{\prime}+f
$$

where $\hat{c}, c$ are calculated values of the substance concentrations on $(n+1)$-th and $n$-th time layers respectively; $\bar{c}=\sigma \hat{c}+(1-\sigma) c ; \sigma \in[0,1]$ is the scheme weight.

The computational domain is a set of rectangular cells that are partially filled, where $o_{i, j}$ is a filling degree of the cell $(i, j)$. The values of computational fields (impurity concentrations, velocity vector components, etc.) are calculated at the vertices of the cells.

The coefficients $q_{0}, q_{1}, q_{2}, q_{3}, q_{4}$, were introduced to describe the complex geometry of the calculated objects. It describe the fullness of cells located in the vicinity of $(i, j)$ cell: $q_{0}-D_{0}$ : $x \in\left(x_{i-1 / 2}, x_{i+1 / 2}\right), \quad y \in\left(y_{j-1 / 2}, y_{j+1 / 2}\right) ; \quad q_{1}-D_{1}: x \in\left(x_{i}, x_{i+1 / 2}\right), y \in\left(y_{j-1 / 2}, y_{j+1 / 2}\right) ; \quad q_{2}-D_{2}:$ 
$x \in\left(x_{i-1 / 2}, x_{i}\right), \quad y \in\left(y_{j-1 / 2}, y_{j+1 / 2}\right) ; \quad q_{3}-D_{3}: x \in\left(x_{i-1 / 2}, x_{i+1 / 2}\right), \quad y \in\left(y_{j}, y_{j+1 / 2}\right) ; q_{4}-D_{4}:$ $x \in\left(x_{i-1 / 2}, x_{i+1 / 2}\right), y \in\left(y_{j-1 / 2}, y_{j}\right)$, etc. $\Omega_{m}$ are filled parts of $D_{m}$ domains, $m=\overline{0,4}$. The occupancy coefficients are calculated according to the following formulas:

$$
\begin{gathered}
\left(q_{m}\right)_{i, j}=\frac{S_{\Omega_{m}}}{S_{D_{m}}},\left(q_{0}\right)_{i, j}=\frac{o_{i, j}+o_{i+1, j}+o_{i+1, j+1}+o_{i, j+1}}{4},\left(q_{1}\right)_{i, j}=\frac{o_{i+1, j}+o_{i+1, j+1}}{2} \\
\left(q_{2}\right)_{i, j}=\frac{o_{i, j}+o_{i, j+1}}{2},\left(q_{3}\right)_{i, j}=\frac{o_{i+1, j+1}+o_{i, j+1}}{2},\left(q_{4}\right)_{i, j}=\frac{o_{i, j}+o_{i+1, j}}{2}
\end{gathered}
$$

An adaptive modified alternating-triangular method (MATM) of variational type was used to solve the grid equations arising during discretization [15].

Parallel implementation. Multiprocessor computer systems (MCS) are widely used to solve this class of problems. A set of application programs was created to simulate the microbiological destruction processes of oil pollution in shallow water. it allows to calculate the pollution concentrations in areas of complex shape, take into account factors affecting the pollution spread in water (weather conditions, the influence of coastline and bottom relief); conduct a research of the dependence of pollution concentrations, the degree and size of the affected water area on the intensity of water flow, hydrophysical parameters, climatic and meteorological factors [16].

Using the created software package, we can: to improve and implement the system of integrated fisheries monitoring in water (observation, assessment and forecast of the state of the ecosystem regime, feed base and stocks of fishing facilities); to develop, coordinate of proposals and measures to ensure the optimal regime, conservation of the biodiversity of fishing resources, ecosystems of shallow waters; to improve the methodology of environmental research, development of new, testing and implementation of promising methods for researching the water ecosystems' state and individual components; to develop and improve methods for diagnosing the toxic effects of pollutants on hydrobionts, including early and differential diagnosis of toxicosis, as well as to search the antidote protection of aquatic ecosystems; to organize and conduct the research to identify trends and patterns of changes in the water ecosystems' state under the influence of anthropogenic factors, developing proposals and measures to reduce and prevent such impacts; to assess the damage to fisheries caused by various types of economic activities, development of proposals for the prevention, reduction and adequate compensation of damage.

The velocity fields of the water flow calculated in [17] are the input data for the used model of microbiological destruction of petroleum hydrocarbons. The successively thickening rectangular grids with dimensions $251 \times 351 \times 15,502 \times 702 \times 30,1004 \times 1404 \times 60, \ldots$ were used for simulation the hydrogeological and hydrodynamic processes in a three-dimensional region of complex shape (for example, Azov Sea). For the uniform distribution of computational resources of the problem [18, 19], a parallel adaptive MATM algorithm was developed using the developed schemes of high order of accuracy, based on the decomposition of computational domain in one and two spatial directions, for solving computationally labors hydrophysics problems taking into account the architecture and parameters of multiprocessor computer system [20].

The initial distribution of petroleum hydrocarbons was taken into account in the form corresponding to the spatial and temporal scales of the simulated processes. The implemented 
numerical solution algorithm allows to freely varying the boundary conditions, the type of control functions and the values of corresponding parameters [21]. Understanding the mechanism of the system functioning and knowledge of its main characteristics allowed us to use a phenomenological approach to overcome difficulties at configuring the program. The effectiveness of this approach is also quite high because the behavior of the system is often determined by the accuracy of their ratios, not individual parameters [22]. The high-level language $\mathrm{C}++$ was used at developing the software., The Message Transfer Interface (MPI) technology was used for cluster systems.

Calibration and verification of the developed model of microbiological destruction of oil pollution in a shallow reservoir was performed on the basis of environmental data obtained during research expeditions conducted by scientists of the Southern Federal University since 2000, environmental databases, satellite monitoring. Fig. 4 shows the radar images of the northern part of the Black Sea, the Kerch Strait and the southern part of the Azov Sea, obtained from the Radarsat-1 satellite for November 23, 2007. [23].

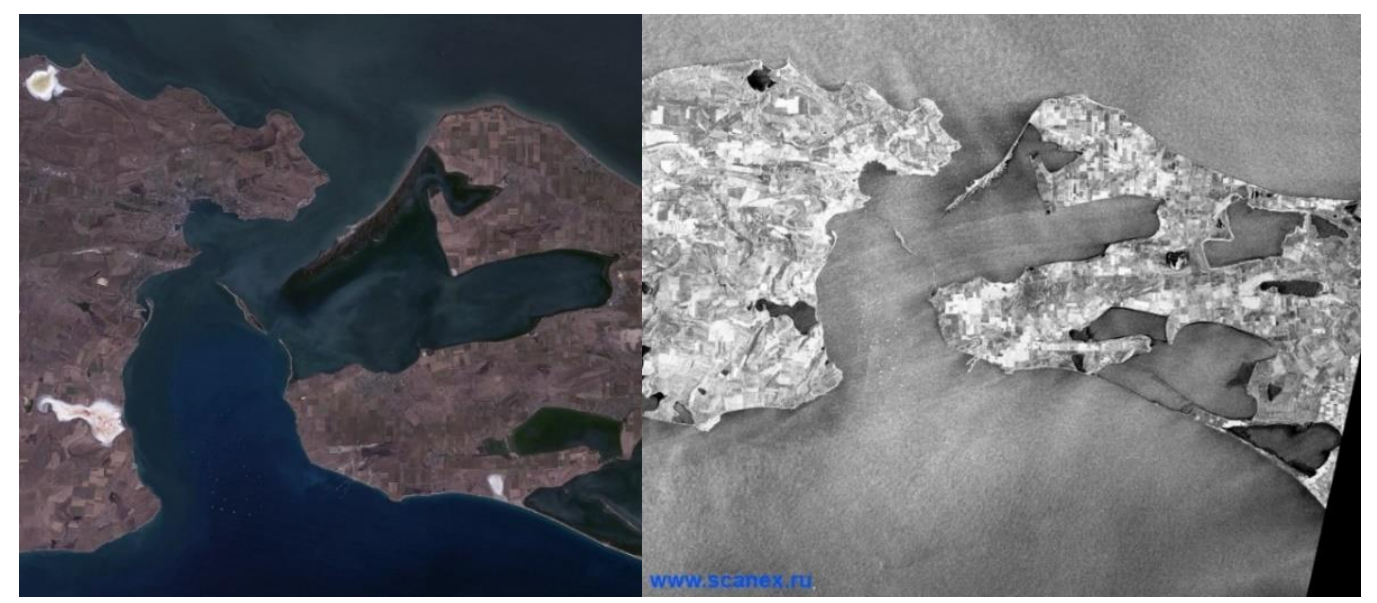

Fig. 4. Overview satellite images of the oil spill site in the Kerch Strait, obtained from the Radarsat-1 satellite for November 23, 2007

Results of software implementation for numerical modeling of the microbiological destruction process of petroleum hydrocarbons by introducing oil-oxidizing bacteria into the coastal system (Azov Sea) are given in Fig. 5, $N$ is the iteration number. Fig. 5a shows the initial distribution of the light oil fraction; Fig. 5b shows the distribution of the light oil fraction (two oil slicks). Fig. 5c shows the initial distribution of the heavy fraction of oil pollution; Fig. $5 \mathrm{~d}$ shows the distribution of the heavy fraction concentration of oil pollution (a single localized slick with the deposition of oil carbon to the water bottom).

The time simulation interval was 30 days (Fig. 5b). The decrease of sorbed oil by $30-40 \%$ was obtained at the initial oil contamination (two oil slicks). This corresponds to the oil distribution process in water compared with satellite data at the qualitative and quantitative levels.

According to the available data of field experiments to research the crude oil destruction in seawater, only $3-15 \%$ of the initial amount of crude oil is subject to oxidation, biodegradation, photochemical reactions, while from 10 to $40 \%$ evaporates. The peak of its solubility was on the 10 th day of exposure (Fig. 6) [24]. 


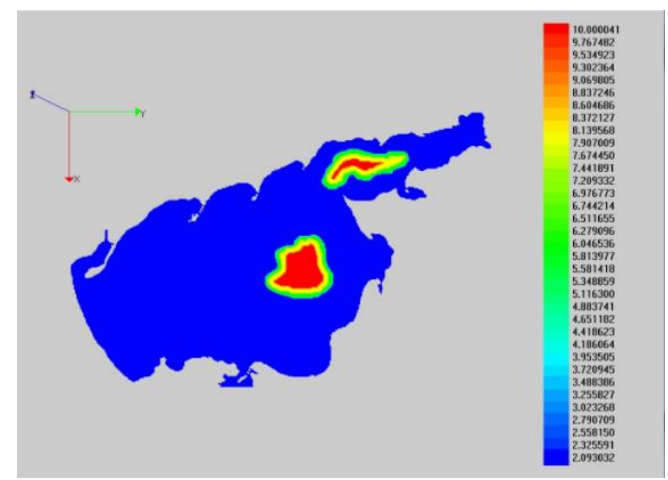

a)

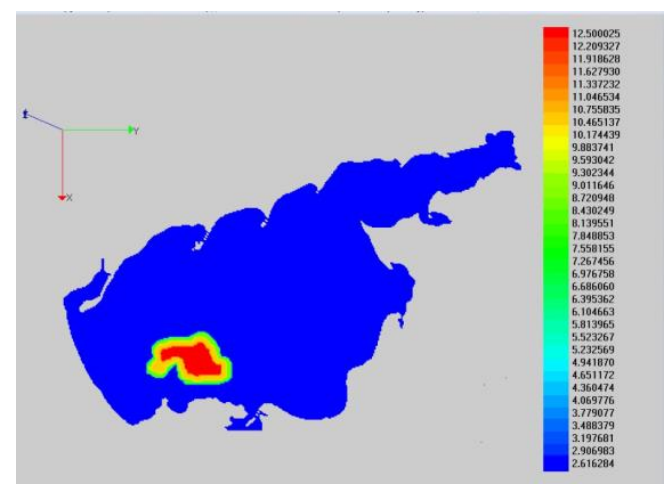

c)

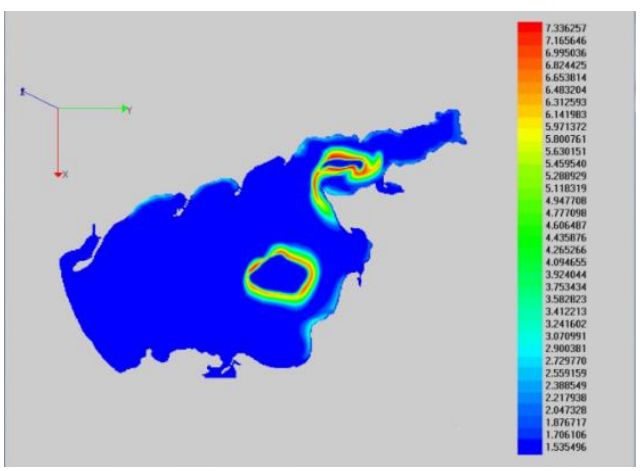

b)

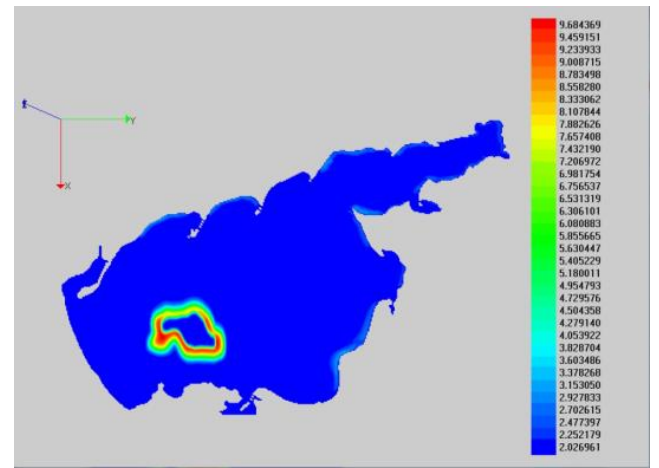

d)

Fig. 5. Results of software operation (changes in the concentration of petroleum hydrocarbons): $\mathrm{a}$ - the initial distribution of the light oil fraction; $\mathrm{b}$ - the distribution of the light oil fraction, $\mathrm{N}=121$ ); $\mathrm{c}$ - the initial distribution of the heavy oil fraction; $\mathrm{d}$ - the distribution of the heavy oil fraction, $N=148$.

According to the regulatory and methodological rules, when a message about a spill of oil and petroleum products is received, the time for spill localization should not exceed 4 hours for a spill in the water area, 6 hours for a spill on the ground from the moment of detection of oil and petroleum products spill from the moment of receipt the information about the spill. We consider the case when measures have not been taken to localize oil spills. It follows from the results of field experiments that the calculated interval should be 20-30 days.

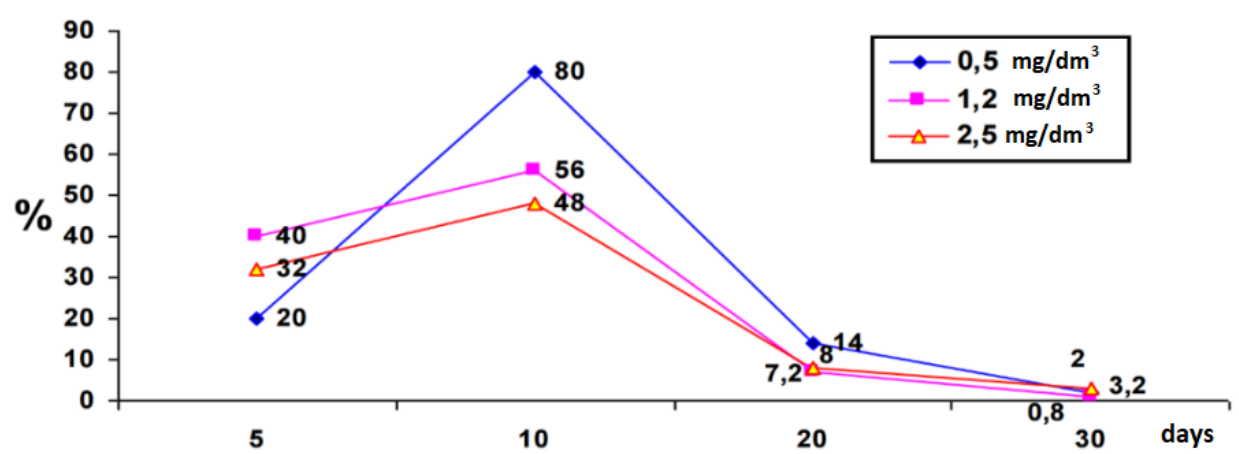

Fig. 6. Dynamics of crude oil degradation in water for light, medium and heavy fractions

The criterion for checking the adequacy of the developed mathematical hydrobiology models of shallow water used in the software was the estimation of simulation error with simultaneous consideration of full-scale data on the available $n$ measurements, which was calculated by the 
formula: $\delta=\sqrt{\sum_{k=1}^{n}\left(c_{k \text { nat }}-c_{k}\right)^{2}} / \sqrt{\sum_{k=1}^{n} c_{k n a t}^{2}}$, where $c_{k \text { nat }}$ is the concentration value obtained by field measurements; $c_{k}$ is the concentration value calculated using the model (1) - (3). The error value at calculation the concentration of oil pollution and microorganisms was 10-20\%.

Conclusion. As part of the research of the main processes occurring in waters and directly affecting the dynamics of oil pollution spread, it was shown that to improve the simulation accuracy, it is necessary to take into account the processes of evaporation, biological destruction, dissolution and spreading, diffusion and dispersion, changes in horizontal turbulent diffusion in hydrodynamic models. The features of the microbiological destruction of petroleum hydrocarbons in water environment were researched. A model of oil transport in shallow waters has been developed, which differs from the known ones by taking into account a number of determining factors: neutral and nonevaporating pseudo-fractions of oil slick; evaporation of the light fraction; dissolution and spreading of oil slick; precipitation; diffusion; advection and biodegradation, which allows to increase the accuracy of modeling the of petroleum products distribution in shallow waters. The approximation of the diffusion-convection problem was performed on the basis of schemes with weights, taking into account the partial filling of computational cells. The software implementation of the developed mathematical model of oil transport in shallow water was performed on MCS with distributed memory. A complex of applied programs was created that combines mathematical models and environmental databases, with the help of which the conditions of microbiological destruction processes of oil in shallow water were researched. The developed software package includes blocks for simulation the dynamics of oil pollution spread in shallow water taking into account the evaporation of light, neutral and non-evaporating pseudo-fractions of an oil slick, the dissolution of an oil slick and microbiological destruction. Based on multiprocessor computer system, experimental software was developed for mathematical modeling of possible scenarios for the development of shallow water ecosystems on the example of the Azov-Black Sea basin during oil spills. Adapted for a shallow water (Azov Sea), subject to strong anthropogenic impact, the complex uses variational methods of data assimilation and can be used for predictive modeling of the researched phenomena and processes, is one of the effective means of analyzing aquatic ecosystems and managing the quality of their waters.

The comparison of created software for MCS, which implements the developed scenarios for the development of ecological situation in the Azov Sea using the numerical implementation of the developed model problem of biological kinetics, with similar works in the field of mathematical modeling of hydrobiological processes, was performed. As a result, it was possible to increase the simulation accuracy of changes in the oil pollution and microorganisms' concentrations by $10-20 \%$.

\section{References}

1. Rosenberg, G.S., Zinchenko, T.D. Stability of hydroecosystems: a review of the problem // Arid ecosystems. - 2014. - № 4 (61). - P. 11-23 (In Russian).

2. Fay, J.A. Physical processes in the spread of oil on a water surface // Proc. of the Joint conf. prevention and control oil spills. - Washington: Amer. Petrol. Inst. - 1971. - P. 463-467. 
3. Keyyong, Hong. A real-time simulation of the trajectory and fate of spilled oil at sea / Keyyong Hong, Sun-Young Kim // Korea Research Institute of Ships and Ocean Engineering. - International oil spill conference. - 1997. - P. 573-577.

4. Carracedo, P., Torres-Lopez, S., Barreiro, M., Montero, P., Balseiro, C.F., Penabad, E., Leitao, P.C., Perez-Munuzuri, V. Improvement of pollutant drift forecast system applied to the Prestige oil spills in Galicia Coast (NW of Spain): Development of an operational system // Marine Pollution Bull. - 2006. - Vol. 53. - P. 350-360.

5. Sukhinov, A.I., Chistyakov, A.E., Nikitina, A.V., Belova, Y.V., Sumbaev, V.V., Semenyakina, A.A. Supercomputer Modeling of Hydrochemical Condition of Shallow Waters in Summer Taking into Account the Influence of the Environment // Communications in Computer and Information Science. - 2018. - P. 336-351. - DOI: 10.1007/978-3- 319-99673-8.

6. Xie, H., Yapa, P.D., Nakata, K. Modeling emulsification after an oil spill in the sea // J. of Marine Systems. - 2007. - Vol. 68. - P. 489-506.

7. Lapin D. V., Cherchago A. A., Chistyakov A. E. Joint expedition researches of hydrophysical parameters of the Azov Sea on the multipurpose yacht "Burevestnik" and NIS t/x "Platov" // Izvestiya SFedu. Technical sciences. - 2009. - № 8(97). - P. 82-89 (On Russian).

8. Sukhinov, A.I., Nikitina, A.V., Chistyakov, A.E., Sumbaev, V.V., Abramov, M., Semenyakina, A.A. Predictive modeling of suffocation in shallow waters on a multiprocessor computer system // Lecture Notes in Computer Science. 2017. - P. 172-180. - DOI: 10.1007/978-3-319-62932-2_16.

9. Matishov, G.G., Ilyichev, V.G. On optimal exploitation of water resources. The concept of internal prices // Reports of the Academy of Sciences. - 2006. - Vol. 406, № 2. - P. 249-251 (In Russian).

10. Reed, M., Johansen, O., Brandvik, P.J., Daling, P., Lewis, A., Fiocco, R., Mackay, D., Prentki, R. Oil spill modeling towards the close of the 20th century: overview of the state of the art // Spill Science and Technology Bulletin. - 1999. - Vol. 5, № 1. - P. 3-16.

11. Dembitsky S.I., Urtenov M.Kh., Sharpan M.V. Mathematical modeling and analysis of biological destruction of oil at different methods of applying biological products // Ecological systems and devices. 2007. - №11 (In Russian).

12. Nakhushev, A.M. Uravneniia matematicheskoi biologii [Equations of Mathematical Biology]. Moscow, Vysshaia shkola. - 1995. - 301 pp. (In Russian).

13. Chetverushkin, B.N. Resolution limits of continuous media models and their mathematical formulations // Math. Models Comput. Simul. -2013. - Vol. 5, №3. - P. 266-279.

14. Sukhinov, A.I., Chistyakov, A.E., Isayev, A. Nikitina, A.V., Sumbaev, V.V., Semenyakina, A.A.: Complex of Models, High-Resolution Schemes and Programs for the Predictive Modeling of Suffocation in Shallow Waters // Communications in Computer and Information Science. - 2017 - Vol. 753. - P. 169-185 DOI: 10.1007/978-3-319-67035-5_13.

15. Sukhinov, A.I., Chistyakov, A.E. Adaptive modified alternating triangular iterative method for solving grid equations with a non-self-adjoint operator // Mathematical Models and Computer Simulations. 2012. - Vol. 4, № 4. - P. 398-409.

16. Sukhinov, A.I., Chistyakov, A.E., Ugol'nitskii, G.A., Usov, A.B., Nikitina, A.V., Puchkin, M.V., Semenov, I.S. Game-theoretic regulations for control mechanisms of sustainable development for shallow water ecosystems // Automation and Remote Control. - 2017. - Vol. 78, № 6. - P. 1059-1071. - DOI: $10.1134 /$ S0005117917060078

17. Sukhinov, A.I. Mathematical model for calculating coastal wave processes / A.I. Sukhinov, A.E. Chistyakov, E.F. Timofeeva, A.V. Shishenya // Mathematical Models and Computer Simulations. - 2013. Vol. 5, № 2. - P. 122-129.

18. Belotserkovskii, O.M., Gushchin, V.A., Shchennikov, V.V.: Decomposition method applied to the solution of problems of viscous incompressible fluid dynamics // Comput. Math. Math. Phys. - 1975. - № 15. - P. 197-207 (1975).

19. Voevodin, V.V., Voevodin, Vl.B. Parallel computingю - SPB.: BHV-Petersburg. - 2002. - 608 p. (In Russian).

20. Semenyakina, A., Protsenko, S. Complex of parallel programs for modeling oil products transport in coastal systems // MATEC Web of Conferences. - 2017. - P. 04016. 
21. Nikitina, A.V., Semenyakina, A.A., Chistyakov, A.E. Parallel implementation of the diffusionconvection problem based on high-order accuracy schemes // Bulletin of Computer and Information Technologies. - 2016. - № 7 (145). - P. 3-8 (In Russian).

22. Sukhinov, A.I., Chistyakov, A.E., Nikitina, A.V., Lyashchenko, T.V., Filina, A.A., Litvinov, V.N. The use of supercomputer technologies for predictive modeling of pollutant transport in boundary layers of the atmosphere and water bodies // Communications in Computer and Information Science. 2019. - Vol. 1063. - P. 225-241.

23. GIS-Association. URL: http://www.gisa.ru/assoc.html

24. Delvigne, G.A.L., Swinney, C.E. Natural dispersion of oil // Oil and Chemical Pollution. -1988. - Vol. 17. - P. 281-310.

\section{Authors:}

Filina Alena, Supercomputers and Neurocomputers Research Center, Co Ltd. (Italyansky lane, 106, Taganrog, Russian Federation), Candidate of Technical Science, Scientific Researcher, j.a.s.s.y@mail.ru

Sidoryakina Valentina, Taganrog Institute of A.P. Chekhov (branch) RSUE (Initiative Street, Taganrog, Russian Federation), Candidate of Science in Physics and Maths, Associate professor

Chistyakov Alexander, Don State Technical University, (Gagarin square, 1, Rostov-on-Don, Russia), Doctor of Science in Physics and Maths, Professor. Email address: cheese 05@mail.ru

Nikitina Alla, Southern Federal University (Chekhov str., 2, Taganrog, Russian Federation), Doctor of Technical Science, Associate professor, nikitina.vm@gmail.com 


\title{
МОДЕЛИРОВАНИЕ ПРОЦЕССА МИКРОБИОЛОГИЧЕСКОЙ ДЕСТРУКЦИИ ЗАГРЯЗНЕНИЯ НЕФТЯНОГО ПРОИСХОЖДЕНИЯ В МЕЛКОВОДНОМ ВОДОЕМЕ *
}

\author{
А.А. Филина ${ }^{1}$, В.В. Сидорякина ${ }^{2}$, А.Е. Чистяков ${ }^{3}$, А.В. Никитина ${ }^{3,4}$ \\ ${ }^{1}$ Научно-исследовательский центр супер-ЭВМ и нейрокомпьютеров, Таганрог, Россия \\ ${ }^{2}$ Таганрогский институт имени А.П. Чехова (филиал) ФГБОУ ВО «РГЭУ (РИНХ)», Таганрог, Россия \\ ${ }^{3}$ Донской государственный технический университет, Ростов-на-Дону, Россия \\ ${ }^{4}$ Южный федеральный университет, Ростов-на-Дону, Россия
}

$\square$ j.a.s.s.y@mail.ru, cvv9@mail.ru, cheese_05@mail.ru,nikitina.vm@gmail.com

Статья посвящена исследованию процессов микробиологической деструкции загрязняющих веществ нефтяного происхождения в мелководном водоеме с учетом ряда определящих факторов, влияющих на картину распределения загрязнения в акватории исследуемого водного объекта: фракционного состава нефти, процессов испарения, растворения, биологического окисления нефтеуглеводородов микроорганизмами, а также гидродинамических и химико-биологических особенностей водоема. Предложен комплекс взаимосвязанных пространственно-неоднородных математических моделей, позволяющих изучать динамику процессов микробиологической деструкции нефтяных углеводородов в мелководном водоеме. При дискретизации моделей были разработаны схемы с весами, учитывающие частичную заполненность расчетных ячеек моделируемой области, что позволило существенно повысить точность расчетов и сократить время вычислений. На базе многопроцессорной вычислительной системы разработано экспериментальное программное обеспечение, предназначенное для прогнозного моделирования экологической обстановки мелководного водоема в случае аварийного загрязнения нефтью и другими вредными веществами при природных и техногенных вызовах.

Ключевые слова: микробиологическая деструкция, нефть, мелководный водоем, параллельный алгоритм, комплекс программ, вычислительная система

\footnotetext{
* Исследование выполнено при финансовой поддержке РФФИ в рамках научного проекта № 19-01-00701.
} 
Авторы:

Филина Алёна Александровна, Научно-исследовательский центр супер-ЭВМ и нейрокомпьютеров (347900, Таганрог, пер. Итальянский, д. 106), кандидат технических наук, научный сотрудник, j.a.s.s.y@mail.ru

Сидорякина Валентина Владимировна, Таганрогский институт им. А.П. Чехова (филиал) РГЭУ (РИНЭ) (347936 Таганрог, ул. Инициативная, д. 48), кандидат физико-математических наук, доцент, cvv9@mail.ru

Чистяков Александр Евгеньевич, Донской государственный технический университет (344000, Ростов-на-Дону, пл. Гагарина, 1), доктор физико-математических наук, профессор, cheese05@mail.ru

Никитина Алла Валерьевна, Южный федеральный университет (347900, Таганрог, ул. Чехова, 2), доктор технических наук, профессор, nikitina.vm@gmail.com 